\title{
Nitrogen Source for Inflorescence Development in Phalaenopsis: I. Relative Significance of Stored and Newly Absorbed Nitrogen
}

\author{
Hadi Susilo, Ying-Chun Peng, and Yao-Chien Alex Chang ${ }^{1}$ \\ Department of Horticulture and Landscape Architecture, National Taiwan University, 1 Roosevelt \\ Road Sec. 4, Taipei 10617, Taiwan
}

\begin{abstract}
AdDITIONAL INDEX wORDS. moth orchid, nitrogen-15, nitrogen partitioning, nutrient mobilization, sink-source relationship, stable isotope

ABstract. Phalaenopsis orchid is a slow-growing crop that responds slowly to fertilization. In this study, we used ${ }^{15} \mathrm{~N}-$ labeled Johnson's solution to investigate the accumulation and use of fertilizer nitrogen $(N)$ during the vegetative and reproductive growth stages of Phalaenopsis Sogo Yukidian 'V3' with a focus on the nitrogen source for inflorescence development. Labeling of fertilizer applied to mature plants 6 weeks before forcing or at 6 weeks into forcing showed that in the inflorescence, the ratio of $\mathrm{N}$ derived from fertilizer applied 6 weeks before forcing to the $\mathrm{N}$ derived from fertilizer applied 6 weeks into forcing was $31 \%$ to $69 \%$, which shows the importance of newly absorbed fertilizer for supplying the $\mathbf{N}$ needed for inflorescence development. The fate of fertilizer $\mathbf{N}$ applied during the small, medium, or large plant stage of vegetative Phalaenopsis Sogo Yukidian 'V3' was traced separately with ${ }^{15} \mathrm{~N}$-labeling. The capacity of the plant to accumulate $\mathrm{N}$ after fertilizer application was different during the various stages of vegetative growth, with large plants having more $N$ storage capacity as a result of their greater biomass. However, the percentage of the accumulated $N$ that was later allocated to the inflorescence was similar regardless of the stage of fertilizer application: of the fertilizer $\mathrm{N}$ absorbed during various stages of the vegetative period, $6 \%$ to $8 \%$ was allocated to the inflorescence at the visible bud stage. This result highlights the mobility of $N$ stored early on within the plant. By calculation, of the total $\mathbf{N}$ in the inflorescence at the visible bud stage, the $\mathbf{N}$ absorbed during the small, medium, and large plant stages contributed $7 \%, 11 \%$, and $25 \%$, respectively, whereas $\mathrm{N}$ applied after spiking made up the other $57 \%$. This result indicates that both $N$ stored during the vegetative stage and $N$ applied during the reproductive stage contribute significantly to inflorescence development.
\end{abstract}

Phalaenopsis is currently the most important pot flower in market value in the world's major floriculture markets (FloraHolland, 2013; U.S. Department of Agriculture, 2013). One characteristic of Phalaenopsis orchids is the long vegetative period before the plants are ready to be forced into marketable flowering plants (Runkle et al., 2005). Flowering in Phalaenopsis orchids is easily achieved by low temperature and conversely inhibited by high temperature (Lee and Lin, 1984).

Sphagnum moss is a popular potting substrate in the commercial production of Phalaenopsis. In this substrate, greenhouse-grown standard-type Phalaenopsis plants in Taiwan and plants grown elsewhere using the Taiwanese method generally undergo three stages during the vegetative stage and are potted-up twice: from $4.5-$ to $8.5-\mathrm{cm}$ pots, and finally to $10.5-\mathrm{cm}$ pots, in which plants are grown until flowering. In this study, we refer to the respective three vegetative stages as Stage I (small plant in $4.5-\mathrm{cm}$ pot for 5 months), Stage II (medium plant in $8.5-\mathrm{cm}$ pot, 5 months), and Stage III (large plant in 10.5-cm pot, 5 months).

Received for publication 19 Sept. 2013. Accepted for publication 2 Dec. 2013. This research was funded by a grant from the National Science Council, Executive Yuan, Taiwan (NSC 98-2313-B-002-014-MY3).

This study consists of portions of the theses submitted by Hadi Susilo and YingChun Peng in partial fulfillment of their Master of Science degree requirements. We thank Yu-Chun Chen and Yi-Ai Guo for their assistance in the early part of Expt. 2. We are grateful to Ya-Chi Yu for helpful discussions in Expt. 2. We also thank the Stable Isotope Facility at the University of California, Davis for performing the ${ }^{15} \mathrm{~N}$ analysis.

${ }^{1}$ Corresponding author. E-mail: alexchang@ntu.edu.tw.
Nitrogen is an important macronutrient that significantly affects the growth and flowering of Phalaenopsis (Lei, 2007; $\mathrm{Yu}, 2012$ ), whereas $\mathrm{N}$ needs during flowering are of particular interest. To our knowledge, the relative contributions of stored $\mathrm{N}$ and recently absorbed fertilizer $\mathrm{N}$ to the developing inflorescence have not been studied in Phalaenopsis. The relative contributions to the stored $\mathrm{N}$ pool of $\mathrm{N}$ accumulated during the different growth stages during the long vegetative period of Phalaenopsis cultivation were also unknown. The objective of this study is to bring answers to these unknowns.

${ }^{15} \mathrm{~N}$-labeling is a powerful research tool for accurately determining the fate of $\mathrm{N}$ in the environment (Hauck and Bremner, 1976). The nutritional study of Phalaenopsis is difficult with traditional methods because it has a strong buffering capacity against nutrient deficiency, but we have used ${ }^{15} \mathrm{~N}$-labeling with the enrichment method to accurately trace the absorption and partitioning of fertilizer $\mathrm{N}$ in Phalaenopsis (Susilo et al., 2013). In this study, we used ${ }^{15} \mathrm{~N}$-labeling to compare the contributions of fertilizer $\mathrm{N}$, applied before or after spiking, to the developing inflorescence and compare the relative contributions of fertilizer $\mathrm{N}$ absorbed during various stages of the vegetative period to the stored $\mathrm{N}$ pool.

\section{Materials and Methods}

EXPt. 1: AbSORPtion AND PARTITIONING OF FERTILIZER $\mathbf{N}$ BEFORE AND AFTER LOW-TEMPERATURE FORCING. The objective of this experiment was to determine the absorption and partitioning of $\mathrm{N}$ in Phalaenopsis plants before and after lowtemperature forcing as well as the source of $\mathrm{N}$ being used for 
inflorescence development. Vegetatively propagated plants of the white, large-flowered Phalaenopsis Sogo Yukidian 'V3' in $10.5-\mathrm{cm}$ pots with five or six leaves were used. The experiment was conducted over a period of 18 weeks. The ${ }^{15} \mathrm{~N}$-labeling treatments were performed by subirrigating the plants once with modified Johnson's solution (Johnson et al., 1957) labeled with 11.25 atom $\%{ }^{15} \mathrm{~N}$ at various points in time: 1) no labeling treatment (control); 2) ${ }^{15} \mathrm{~N}$-labeling at the start of the experiment (6 weeks before low-temperature forcing); 3) ${ }^{15} \mathrm{~N}$-labeling 6 weeks after low-temperature forcing was initiated; and 4) ${ }^{15} \mathrm{~N}$ labeling both at the start of the experiment and 6 weeks after low-temperature forcing was initiated. There were four treatments with six replications each. The timing of the single application of ${ }^{15} \mathrm{~N}$ label was designed as such, so that plants were exposed to ${ }^{15} \mathrm{~N}$-enrichment for the same duration (6 weeks) after each ${ }^{15} \mathrm{~N}$ application. In the first 6 weeks of the experiment, the plants were grown in a phytotron at $30 / 25^{\circ} \mathrm{C}$ (day/night) under natural photoperiod and maximum light intensity of $450 \mu \mathrm{mol} \cdot \mathrm{m}^{-2} \cdot \mathrm{s}^{-1}$ at National Taiwan University (Taipei, Taiwan) to maintain vegetative growth. After the 6week period, the roots of all plants were cleaned of the old substrate, washed with tap water, and the plants were repotted into fresh substrate to cease ${ }^{15} \mathrm{~N}$ enrichment in the substrate surrounding the roots. The plants were then transferred to a phytotron at $25 / 20{ }^{\circ} \mathrm{C}$ (day/night) with maximum light intensity of $450 \mu \mathrm{mol} \cdot \mathrm{m}^{-2} \cdot \mathrm{s}^{-1}$ for 12 weeks for forcing into the reproductive stage. At the time ${ }^{15} \mathrm{~N}$-labeling was conducted in Treatments 3 and 4 (6 weeks into low-temperature forcing), the plants had spikes $\approx 5 \mathrm{~cm}$ long.

All plants were fertigated at the same time by subirrigating with Johnson's solution when the surface of the substrate appeared dry. Except when ${ }^{15} \mathrm{~N}$-labeling was being performed, unlabeled Johnson's solution was used for fertigation. All plants were harvested 18 weeks after the start of the experiment, at which point the inflorescences were at the visible bud stage. Each plant was separated into roots, newly grown leaves (i.e., those that developed after the start of the experiment), mature leaves (all leaves other than newly grown leaves), and inflorescence. After drying, the samples were ground to fine powder and analyzed for total $\mathrm{N}$ and ${ }^{15} \mathrm{~N}$ concentrations.

Expt. 2: Absorption AND PARTITIONing OF FERTILIZER $\mathbf{N}$ APPLIED DURING VARIOUS VEgETATIVE GROWTH STAGES. The objective of this experiment was to investigate the partitioning of fertilizer $\mathrm{N}$ applied at various points of the vegetative stage and the use of this $\mathrm{N}$ during the reproductive stage. Micropropagated plants of Phalaenopsis Sogo Yukidian 'V3' were deflasked, potted in sphagnum moss substrate in $4.5-\mathrm{cm}$ pots, and cultivated in a Venlo-type greenhouse at National Taiwan University with maximum monthly temperature of $27^{\circ} \mathrm{C}$ in summer, minimum monthly temperature of $18^{\circ} \mathrm{C}$ in winter, and maximum light intensity of $400 \mu \mathrm{mol} \cdot \mathrm{m}^{-2} \cdot \mathrm{s}^{-1}$. Plant growth stages during the experiment were as follows: I) vegetative growth in $4.5-\mathrm{cm}$ pots ( 5 months); II) vegetative growth in 8.5 -cm pots ( 5 months); III) vegetative growth in $10.5-\mathrm{cm}$ pots (5 months); and IV) reproductive period. Throughout the experimental period, plants were fertigated with full-strength Johnson's solution when the surface of the medium appeared dry. At the end of Stages I and II, the plants were repotted into fresh sphagnum moss in the next pot size. At the end of Stage III, plants were repotted into fresh sphagnum moss but remained in the same pot size. The purpose of repotting was to replace the existing sphagnum moss with fresh materials so that ${ }^{15} \mathrm{~N}$-labeling was ended at the end of each of Stages I, II, and III.

Plants were divided into five groups and each given one of the following treatments: 1) no ${ }^{15} \mathrm{~N}$ label application (control); 2) single application of ${ }^{15} \mathrm{~N} 3$ months into Stage I; 3) single application of ${ }^{15} \mathrm{~N}$ label 3 months into Stage II; 4) single application of ${ }^{15} \mathrm{~N}$ label 3 months into Stage III; and 5) three ${ }^{15} \mathrm{~N}$ label applications, each done 3 months into Stages I, II, and III. The timing of ${ }^{15} \mathrm{~N}$ label application was designed so that in each of Stages I, II, and III, the plants had the same duration of ${ }^{15} \mathrm{~N}$ labeling of 2 months. ${ }^{15} \mathrm{~N}$-labeling was conducted by subirrigating the pots once with full-strength Johnson's solution enriched with 22.5 atom $\%{ }^{15} \mathrm{~N}$. Seven plants from each treatment group were sampled at each of the following sampling points: 1) first sampling: end of Stage I; 2) second sampling: end of Stage II; 3) third sampling: end of Stage III; 4) fourth sampling: visible bud stage; and 5) fifth sampling: stage where two-thirds of all flowers on the inflorescence were open. Sampled plants were divided into their respective shoots and roots and also inflorescences for the fourth and fifth sampling points. The plant parts were measured for fresh weight and dry weight and then ground to fine powder before total $\mathrm{N}$ and ${ }^{15} \mathrm{~N}$ analysis.

${ }^{15}$ N-LABELING OF FERTILIzER. Modified Johnson's solution was used as the fertilizer in all experiments. It contained $16 \mathrm{~mm}$ $\mathrm{N}, 2 \mathrm{~mm}$ phosphorus, $6 \mathrm{~mm}$ potassium, $4 \mathrm{~mm}$ calcium, $1 \mathrm{~mm}$ sulfur, $1 \mathrm{~mm}$ magnesium, $50 \mu \mathrm{M}$ chlorine, $25 \mu \mathrm{M}$ boron, $5 \mu \mathrm{M}$ manganese, $4 \mu \mathrm{M}$ iron, $2 \mu \mathrm{M}$ zinc, $0.5 \mu \mathrm{M}$ copper, $0.1 \mu \mathrm{M}$ molybdenum, and $0.1 \mu \mathrm{M}$ nickel with an ammonium-to-nitrate ratio of $1: 7 .{ }^{15} \mathrm{~N}$-labeling was achieved by enrichment of the potassium nitrate in the Johnson's solution with 60 atom $\%{ }^{15} \mathrm{~N}$ labeled potassium nitrate (ISOTEC, Miamisburg, OH). In Expt. 1 , the ${ }^{15} \mathrm{~N}$-labeled solution had a ${ }^{15} \mathrm{~N}$ concentration of 11.25 atom $\%$. In Expt. 2, the ${ }^{15} \mathrm{~N}$-labeled solution had a ${ }^{15} \mathrm{~N}$ concentration of 22.5 atom $\%$.

Analysis for total $\mathbf{N}$ AND ${ }^{15} \mathbf{N}$ ISOTOPE AND DATA Calculation. Between 3 and $4 \mathrm{mg}$ of the dried, ground sample was packaged into a $8 \times 5-\mathrm{mm}$ tin capsule (Elemental Microanalysis, Okehampton, U.K.) and the weight of each sample was measured to the last microgram with a microbalance (Mettler Toledo, Columbus, $\mathrm{OH}$ ). The packaged samples were sent to the Stable Isotope Facility at the University of California, Davis for total $\mathrm{N}$ and ${ }^{15} \mathrm{~N}$ analysis, which was done using a PDZ Europa ANCA-GSL elemental analyzer interfaced to an isotope ratio mass spectrometer (PDZ Europa 20-20; Sercon, Crewe, U.K.). The atom percent ${ }^{15} \mathrm{~N}$ excess (atom $\%$ excess) was obtained by subtracting natural abundance of ${ }^{15} \mathrm{~N}$ $(0.366$ atom $\%)$ from the results of the ${ }^{15} \mathrm{~N}$ analysis. The ${ }^{15} \mathrm{~N}$ content excess $=\mathrm{N}$ content $\times$ weight $\%$ of excess ${ }^{15} \mathrm{~N}$ out of total $\mathrm{N}$.

Statistical analysis. The experiments were carried out in a completely randomized design. Statistical tests were done using CoStat software (Version 6.101; CoHort Software, Monterey, CA). Data were subjected to analysis of variance to analyze the effect of treatments. Mean separation among treatments was obtained using the least significant difference test at $P \leq 0.05$. Graphs were plotted with SigmaPlot software (Version 10.0; Systat Software, San Jose, CA).

\section{Results and Discussion}

EXPt. 1: AbSORPtion AND PARTITIONING OF FERTILIZER $\mathbf{N}$ BEFORE AND AFTER LOW-TEMPERATURE FORCING. Because plants received the same amount of fertilizer $\mathrm{N}$ in the various 
treatments, labeling with ${ }^{15} \mathrm{~N}$ during the vegetative stage, the reproductive stage, or during both stages produced no significant difference in the dry weight, $\mathrm{N}$ concentration, or $\mathrm{N}$ content of the various parts sampled (data not shown). Plants had average newly grown leaf, mature leaf, root, inflorescence, and whole-plant dry weights of $4.1,3.9,5.5,1.4$, and $14.9 \mathrm{~g}$, respectively, at the visible bud stage (data not shown). This observation also indicates that the presence or absence of ${ }^{15} \mathrm{~N}$ labeling or its frequency had no effect on the growth and development of the Phalaenopsis plants.

The atom $\%$ excess ${ }^{15} \mathrm{~N}$ in plants that received no ${ }^{15} \mathrm{~N}$ labeling was close to zero (Table 1). In plants labeled with ${ }^{15} \mathrm{~N}$ during the vegetative stage, atom $\%$ excess ${ }^{15} \mathrm{~N}$ was highest in the newly grown leaves, intermediate in roots and inflorescences, and lowest in the mature leaves (Table 1). In plants labeled with ${ }^{15} \mathrm{~N}$ during the reproductive stage, atom $\%$ excess ${ }^{15} \mathrm{~N}$ was highest in roots and inflorescences (Table 1). Labeling with ${ }^{15} \mathrm{~N}$ during both the vegetative stage and the reproductive stage resulted in higher atom\% excess ${ }^{15} \mathrm{~N}$ in the various plant parts compared with treatments with a single application of ${ }^{15} \mathrm{~N}$ label. When plants were ${ }^{15} \mathrm{~N}$-labeled during both the vegetative and reproductive stages, the ${ }^{15} \mathrm{~N}$ concentration was highest in inflorescences and lowest in the mature leaves (Table 1). This result indicates that once matured, leaves become the plant part with the lowest sink activity for $\mathrm{N}$ from recent fertilizer uptake.

Whole-plant ${ }^{15} \mathrm{~N}$ content excess was lowest in plants with no ${ }^{15} \mathrm{~N}$ enrichment with values close to zero found in the various plant parts (Table 2). Whole-plant ${ }^{15} \mathrm{~N}$ content excess was highest in plants that were labeled with ${ }^{15} \mathrm{~N}$ during both the vegetative stage and the reproductive stage, whereas the value was similar in plants labeled during either the vegetative or reproductive stage (Table 2). In plants labeled during the vegetative stage, ${ }^{15} \mathrm{~N}$ content excess was highest in newly grown leaves and roots (Table 2). In plants labeled during the reproductive stage, the ${ }^{15} \mathrm{~N}$ content excess was highest in roots
[609 $\mu \mathrm{g}$ (Table 2)]. In plants labeled with ${ }^{15} \mathrm{~N}$ during both the vegetative and reproductive stages, ${ }^{15} \mathrm{~N}$ content excess was lowest in mature leaves at $212 \mu \mathrm{g}$ and highest in roots at $869 \mu \mathrm{g}$ (Table 2), indicating that overall, roots are a strong sink for $\mathrm{N}$.

SinK STRENGTH FOR $\mathbf{N}$ OF VARIOUS PLANT PARTS AND ITS CHANGE DURING various Growth Stages. Data in Expt. 1 demonstrated that newly grown leaves were the strongest sinks for $\mathrm{N}$ from recent fertilizer uptake during the vegetative stage of Phalaenopsis. When the ${ }^{15} \mathrm{~N}$-labeled fertilizer was applied 6 weeks before the low-temperature forcing, highest ${ }^{15} \mathrm{~N}$ concentration among plant parts was found in newly grown leaves (Table 1). Comparing the proportion of ${ }^{15} \mathrm{~N}$ content excess of various parts against the whole plant, the highest ${ }^{15} \mathrm{~N}$ content excess percentage of $44 \%$ out of the whole-plant value was found in newly grown leaves (Table 2). However, this value decreased to $25 \%$ when ${ }^{15} \mathrm{~N}$-labeled fertilizer was applied during the reproductive stage (Table 2), indicating a decrease in sink strength of newly grown leaves as the growth phase shifted to the reproductive stage. In the reproductive stage, developing inflorescence had a strong sink activity for $\mathrm{N}$, as demonstrated by a high ${ }^{15} \mathrm{~N}$ concentration of 0.668 atom $\%$ excess (Table 1). However, as a result of their smaller dry weight, the sink strength was small, as shown by the proportion of ${ }^{15} \mathrm{~N}$ label in inflorescences, which accounted for only $15 \%$ of the whole-plant value (Table 2).

Roots had significant sink strength for $\mathrm{N}$ throughout the various growth stages. The distribution of ${ }^{15} \mathrm{~N}$ in plants was high in roots [i.e., $35 \%$ to $54 \%$ (Table 2)] regardless of the stage in which ${ }^{15} \mathrm{~N}$-labeling was done. This can be explained by the largest dry weight of roots among the sampled parts (data not shown), and also by high ${ }^{15} \mathrm{~N}$ concentration found in the roots (Table 1). The general observation that high ${ }^{15} \mathrm{~N}$ concentrations were found in roots compared with other plant parts was because roots are strong sinks for N, and they also serve as a site of N storage in Phalaenopsis (Susilo et al., 2013). The

Table 1. Effect of application timing of ${ }^{15} \mathrm{~N}$ fertilizer on ${ }^{15} \mathrm{~N}$ concentration in the newly grown leaves, mature leaves, roots, and inflorescence of Phalaenopsis Sogo Yukidian 'V3'.

\begin{tabular}{|c|c|c|c|c|}
\hline \multirow[b]{2}{*}{ Stage of ${ }^{15} \mathrm{~N}$ application } & \multicolumn{4}{|c|}{${ }^{15} \mathrm{~N}$ concn (atom $\%$ excess) } \\
\hline & Newly grown leaves ${ }^{z}$ & Mature leaves ${ }^{\mathrm{z}}$ & Roots & Inflorescence \\
\hline None & $0.001 \mathrm{~d} \mathrm{~A}^{\mathrm{y}}$ & $0.001 \mathrm{~d} \mathrm{~A}$ & $0.000 \mathrm{~d} \mathrm{~A}$ & $0.001 \mathrm{c} \mathrm{A}$ \\
\hline Vegetative (V) & $0.578 \mathrm{~b} \mathrm{~A}$ & $0.225 \mathrm{~b} \mathrm{C}$ & 0.417 c B & $0.408 \mathrm{~b} \mathrm{~B}$ \\
\hline $\mathrm{V}$ and $\mathrm{R}$ & 0.936 a B & $0.302 \mathrm{a} \mathrm{C}$ & $1.079 \mathrm{a} \mathrm{AB}$ & $1.122 \mathrm{a} \mathrm{A}$ \\
\hline
\end{tabular}

${ }^{\mathrm{z}}$ Newly grown leaves were those that developed after the start of the experiment, whereas mature leaves were the rest of the foliage.

${ }^{\mathrm{y}}$ Means followed by different letters in the same columns (lower case) and rows (upper case) were significantly different by the least significant difference test at $P \leq 0.05(\mathrm{n}=6)$.

Table 2. Effect of application timing of ${ }^{15} \mathrm{~N}$ fertilizer on ${ }^{15} \mathrm{~N}$ content excess in the newly grown leaves, mature leaves, roots, and inflorescence of Phalaenopsis Sogo Yukidian 'V3'.'

\begin{tabular}{|c|c|c|c|c|c|}
\hline \multirow[b]{2}{*}{ Stage of ${ }^{15} \mathrm{~N}$ application } & \multicolumn{5}{|c|}{${ }^{15} \mathrm{~N}$ content excess $(\mu \mathrm{g})$} \\
\hline & Newly grown leaves ${ }^{y}$ & Mature leaves ${ }^{\mathrm{y}}$ & Roots & Inflorescence & Whole plant \\
\hline None & $1 \mathrm{~d} \mathrm{~A}^{\mathrm{x}}$ & $0 \mathrm{dA}$ & $0 \mathrm{cA}$ & $0 \mathrm{~b} \mathrm{~A}$ & $2 \mathrm{c}$ \\
\hline Vegetative (V) & 467 b A $(44 \%)$ & 138 b B $(13 \%)$ & 370 b A $(35 \%)$ & 79 b B $(8 \%)$ & $1053 \mathrm{~b}$ \\
\hline $\mathrm{V}$ and $\mathrm{R}$ & 669 a B $(34 \%)$ & 212 a C (11\%) & 869 a A $(44 \%)$ & 229 a C (11\%) & $1979 \mathrm{a}$ \\
\hline
\end{tabular}

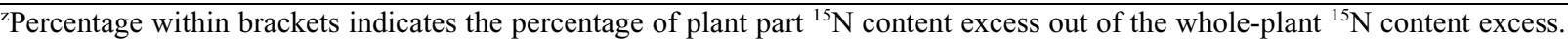

${ }^{y}$ Newly grown leaves were those that developed after the start of the experiment, whereas mature leaves were the rest of the foliage.

${ }^{x}$ Means followed by different letters in the same columns (lower case) and rows (upper case) were significantly different by the least significant difference test at $P \leq 0.05(\mathrm{n}=6)$. 
sink activity and $\mathrm{N}$ storage capability of roots have also been reported in Oncidium orchid (Guo, 2012). In our study, mature leaves were the weakest $\mathrm{N}$ sink with ${ }^{15} \mathrm{~N}$ content excess proportion ranging from $6 \%$ to $13 \%$ of whole-plant ${ }^{15} \mathrm{~N}$ content excess (Table 2) despite their large biomass (data not shown).

Our finding with regard to sink activity for $\mathrm{N}$ in Phalaenopsis is similar to other crops. Tracing of ${ }^{15} \mathrm{~N}$-labeled fertilizer $\mathrm{N}$ revealed that current year's leaf and stem growth of blueberry [Vaccinium corymbosum (Retamales and Hanson, 1989)], the filling seeds of pea [Pisum sativum (Schiltz et al., 2005)], and the fruiting spurs of walnut [Juglans regia (Youssefi et al., 2000)] are all strong sinks for $\mathrm{N}$ from recent fertilizer uptake during the current growing season. Results from our work provide further confirmation to the general consensus that actively growing plant parts are strong sinks for $\mathrm{N}$ from recent fertilizer uptake.

In addition, changes of sink strength for $\mathrm{N}$ during shifts in growth stages such as found in Phalaenopsis in this work have also been reported elsewhere. As pea plants entered the reproductive stage, $86 \%$ of newly applied fertilizer $\mathrm{N}$ was still allocated to the vegetative plant parts, and it was not until seed filling that the allocation dropped to $45 \%$ as a result of the emergence of great sink activity of the filling seeds (Schiltz et al., 2005). In Phalaenopsis, we found in a previous study (Susilo et al., 2013) that the newly grown leaves and roots are strong sinks for $\mathrm{N}$ from fertilizer during the vegetative stage, whereas the inflorescence has a strong sink activity in the reproductive stage. Results in the present study provide further support to our previous findings.

Focusing on the inflorescence ${ }^{15} \mathrm{~N}$ content excess data in Table 2, a higher value was found when the ${ }^{15} \mathrm{~N}$ label was applied during the reproductive stage than during the vegetative stage. The ratio of $\mathrm{N}$ derived from fertilizer applied 6 weeks before forcing to the $\mathrm{N}$ derived from fertilizer applied 6 weeks into forcing was $31 \%$ to $69 \%$, respectively [i.e., 79:174 (calculated from Table 2)].

This observation suggests the importance of recently applied $\mathrm{N}$ for the developing inflorescence in Phalaenopsis. In walnut, foliar application of $\mathrm{N}$ to fruit-bearing spurs resulted in less translocation of the foliar-applied $\mathrm{N}$ to distant plant parts as compared with when foliar $\mathrm{N}$ was similarly applied to the foliage of non-fruit-bearing spurs (Youssefi et al., 2000), in agreement with our observation in Phalaenopsis, in which a significant portion of the total $\mathrm{N}$ accumulated in the developing inflorescence was derived from the recent fertilizer application.

Expt. 2: ABSORPtion AND PARTITIONING OF FERTILIZER $\mathbf{N}$ APPLIED DURING VARIOUS VEGETATIVE GROWTH STAGES. All plants received the same level of fertilization throughout the experiment. As expected, plants that were sampled across treatments at a given point in general had similar dry weight, $\mathrm{N}$ concentration, and $\mathrm{N}$ content in the shoot, roots, inflorescence, and entire plant (data not shown). The average whole-plant dry weights at the first to fifth sampling points were 2.0, 6.5, 14.3, 23.3, and $26.8 \mathrm{~g}$, respectively (data not shown). Whole-plant $\mathrm{N}$ concentrations (on a dry weight basis) at the first to fifth sampling points were $2.00 \%, 2.35 \%, 2.18 \%$, $1.82 \%$, and $1.84 \%$, respectively, with corresponding $\mathrm{N}$ contents of $40,153,312,422$, and $492 \mathrm{mg}$ (data not shown).

Plants not treated with ${ }^{15} \mathrm{~N}$ had ${ }^{15} \mathrm{~N}$ atom\% excess and ${ }^{15} \mathrm{~N}$ content excess close to zero (Figs. 1 and 2). Regardless of the stage of ${ }^{15} \mathrm{~N}$ application, ${ }^{15} \mathrm{~N}$ concentration was highest at the end of the stage of ${ }^{15} \mathrm{~N}$ label application. As the plants entered subsequent growth stages, ${ }^{15} \mathrm{~N}$ concentration continued to decrease (Fig. 1). For instance, whole-plant ${ }^{15} \mathrm{~N}$ concentration in plants receiving ${ }^{15} \mathrm{~N}$ during Stage II was highest at the second sampling point (i.e., end of Stage II), and decreased at subsequent sampling points (Fig. 1D). As the plants grew, $\mathrm{N}$ continued to accumulate in the biomass and hence ${ }^{15} \mathrm{~N}$ was diluted in plants. As plants increased in size from Stage I to III, the capacity to accumulate $\mathrm{N}$ increased owing to the increasing biomass, as shown by higher ${ }^{15} \mathrm{~N}$ content after ${ }^{15} \mathrm{~N}$ application (Fig. 2A-C).

The fifth treatment (i.e., ${ }^{15} \mathrm{~N}$-labeling during Stages I, II, and III) was included to verify the data of the second, third, and fourth treatments. When ${ }^{15} \mathrm{~N}$ content excess data of the various application stages were all added up, the sum was reasonably close to ${ }^{15} \mathrm{~N}$ content excess obtained when ${ }^{15} \mathrm{~N}$ label was applied for all Stages I, II, and III (Fig. 2). For instance, at the fifth sampling point, the sum of whole-plant ${ }^{15} \mathrm{~N}$ content excess accumulated during each of Stages I, II, and III (i.e., 2,276 + $4,170+7,471=13,917 \mu \mathrm{g}$ ) was similar to the whole-plant ${ }^{15} \mathrm{~N}$ content excess obtained when ${ }^{15} \mathrm{~N}$ was applied during all three

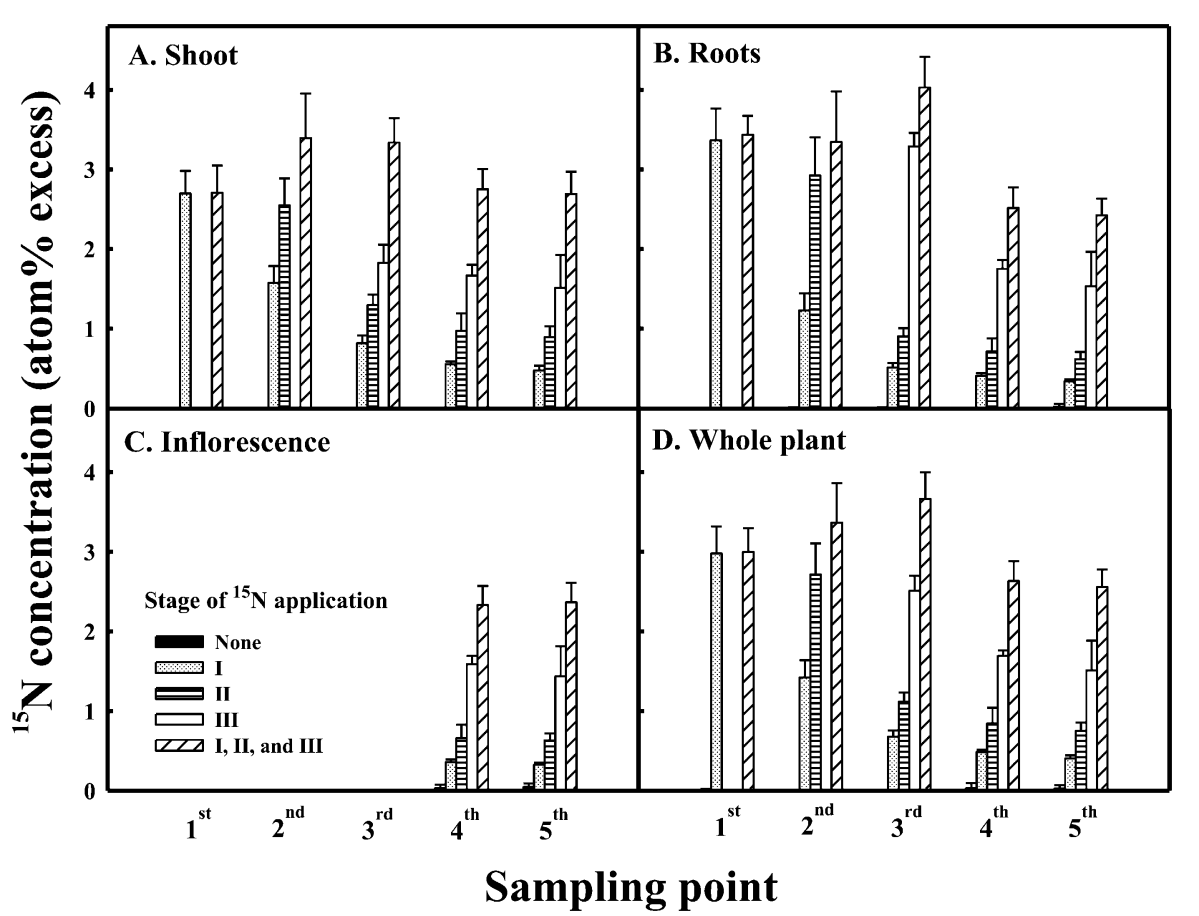

Fig. 1. ${ }^{15} \mathrm{~N}$ concentration at different sampling points in various plant parts of Phalaenopsis Sogo Yukidian 'V3' enriched with ${ }^{15} \mathrm{~N}$ during Stage I, II, or III or during all three stages. Stages I, II, and III were vegetative growth stages in 4.5-, 8.5-, and 10.5-cm pots, respectively. The five sampling points were the end of each of Stages I, II, and III, the visible bud stage, and the two-third flower open stage, respectively. Bars indicate SE $(n=7)$. 


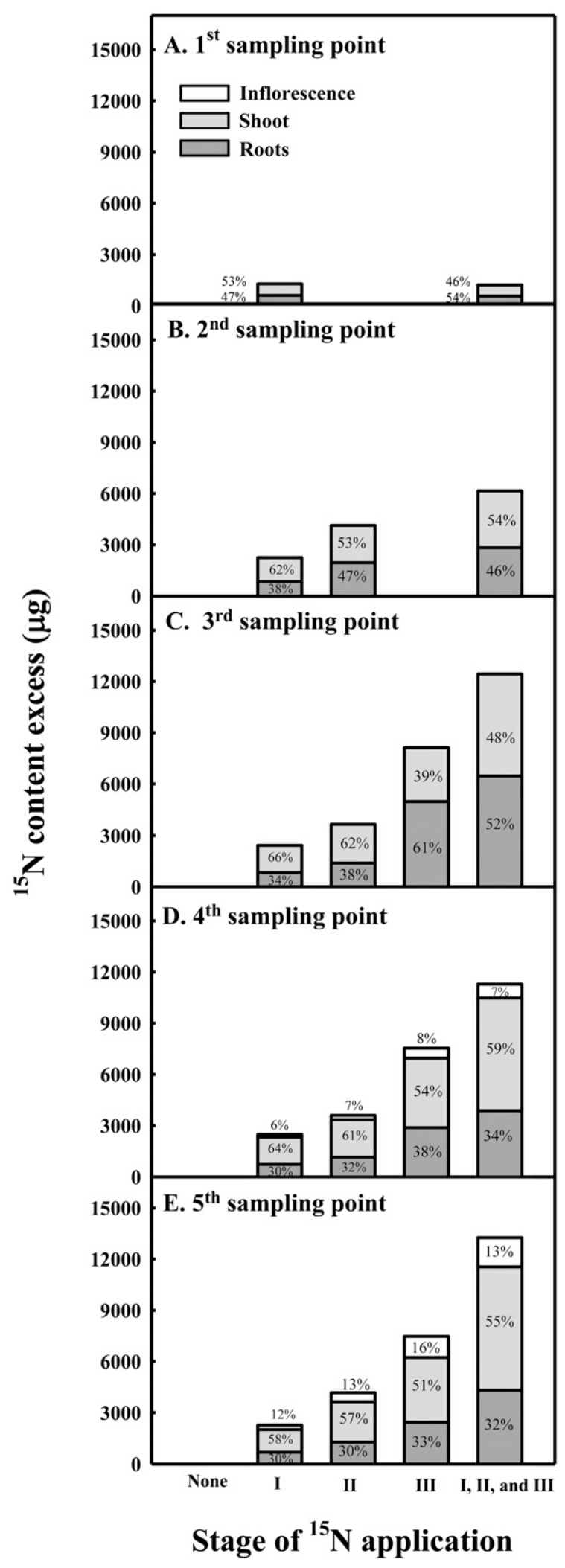

Fig. $2 .{ }^{15} \mathrm{~N}$ content excess at different sampling points in various plant parts of Phalaenopsis Sogo Yukidian 'V3' enriched with ${ }^{15} \mathrm{~N}$ during Stage I, II, or III or during all three stages. Stages I, II, and III were vegetative growth stages in $4.5-, 8.5-$, and $10.5-\mathrm{cm}$ pots, respectively. The five sampling points were the end of each of Stages I, II, and III, the visible bud stage, and the two-third flower open stage, respectively $(n=7)$. stages $\left[13,254 \mu \mathrm{g}\right.$ (Fig. 2E)]. Thus, the ${ }^{15} \mathrm{~N}$ content excess of the second, third, and fourth treatments are verified by this result.

STORAGE AND USE OF FERTILIZER N IN VARIOUS PLANT PARTS THROUGHOUT GROWTH AND FLOWERING. In Expt. 2 , when the ${ }^{15} \mathrm{~N}$ label was applied during Stage I, the shoot accumulated $678 \mu \mathrm{g}$ ${ }^{15} \mathrm{~N}$ label at the end of Stage I, which constituted $53 \%$ of the total ${ }^{15} \mathrm{~N}$ label accumulated. The roots accumulated $607 \mu \mathrm{g}{ }^{15} \mathrm{~N}$, which constituted $47 \%$ of the total (Fig. 2A). Five months later, the allocation of accumulated ${ }^{15} \mathrm{~N}$ label in the shoot and roots became $62 \%$ and $38 \%$, respectively (Fig. 2B).

The partitioning of ${ }^{15} \mathrm{~N}$ applied during Stage II was exactly the same as that found after application during Stage I, whereby the shoot/root ratio of ${ }^{15} \mathrm{~N}$ label was 53:47 and 62:38 at the second and third sampling points, respectively (Fig. 2B-C). These results indicate that during the vegetative stage, $\mathrm{N}$ initially accumulated in roots and then was translocated to the shoot. In a previous study, we found a similar result in which the concentration of ${ }^{15} \mathrm{~N}$ in roots decreased between 4 and 8 weeks after application of ${ }^{15} \mathrm{~N}$ to the roots (Susilo et al., 2013).

After flowering induction, $7 \%$ of the ${ }^{15} \mathrm{~N}$ accumulated during Stage II was found in the inflorescence at the visible bud stage (Fig. 2D). At this time, the percentage of ${ }^{15} \mathrm{~N}$ label in the roots had decreased from $38 \%$ to $32 \%$ (Fig. 2C-D). Between the visible bud stage and the stage when two-thirds of the flowers on the inflorescence were open, the allocation of ${ }^{15} \mathrm{~N}$ label to the inflorescence increased from 248 to $525 \mu$ g [i.e., from $7 \%$ to 13\% (Fig. 2D-E)].

When ${ }^{15} \mathrm{~N}$ label was applied during Stage III, $3146 \mu \mathrm{g}(39 \%)$ and $4969 \mu \mathrm{g}(61 \%)$ of excess ${ }^{15} \mathrm{~N}$ was found in the shoot and roots, respectively, at the end of Stage III (Fig. 2C). When these plants were at the visible bud stage, $8 \%$ of the accumulated ${ }^{15} \mathrm{~N}$ was allocated to the inflorescence. Meanwhile, the allocation of ${ }^{15} \mathrm{~N}$ label to shoot and roots became $54 \%$ and $38 \%$, respectively (Fig. 2D). The decrease in the ${ }^{15} \mathrm{~N}$ content excess in roots during the reproductive stage indicates that $\mathrm{N}$ accumulated in the roots contributed significantly to the $\mathrm{N}$ requirement for inflorescence development in addition to the increased allocation to the shoot.

Between bud visible and the flowers open stage, the allocation to the inflorescence of total ${ }^{15} \mathrm{~N}$ accumulated in the plant during Stage III increased from $8 \%$ to $16 \%$. During this interval, the percentages of ${ }^{15} \mathrm{~N}$ label in both roots and shoot decreased (Fig. 2D-E). These results show that in the early phase of inflorescence development, $\mathrm{N}$ stored in the roots during Stage III was translocated to the inflorescence, whereas during the late stage of inflorescence development, in addition to $\mathrm{N}$ remobilization from roots, translocation of $\mathrm{N}$ stored in the shoot to the inflorescence was also evident. Similar observations were found for ${ }^{15} \mathrm{~N}$ applied during Stages I and II (Fig. 2C-E). These results are in good agreement with our previous report that leaves and roots of Phalaenopsis are storage organs for N (Susilo et al., 2013).

From these results, regardless of the point at which fertilizer $\mathrm{N}$ was applied during the vegetative stage, the absorbed and accumulated $\mathrm{N}$ contributed to inflorescence development during the reproductive stage. Although fertilizer $\mathrm{N}$ accumulated during Stage I was less compared with that during the other stages, $6 \%$ and $12 \%$ of this $\mathrm{N}$, which had been in the plant for more than 1 year, ended up in the inflorescence at the fourth and fifth sampling points, respectively (Fig. 2D-E). Fertilizer N applied during Stage III (i.e., large plants) contributed the most to the inflorescence compared with $\mathrm{N}$ stored at earlier stages of 
the plant's vegetative growth as a result of the increased capacity to accumulate applied $\mathrm{N}$.

The CONTRIBUTION OF $\mathbf{N}$ STORED DURING VARIOUS GROWTH STAGES TO INFLORESCENCE DEVELOPMENT. At the visible bud stage in Expt. 2, 6\%, 7\%, and 8\% of the $\mathrm{N}$ accumulated during Stages I, II, and III, respectively, was allocated to the inflorescence (Fig. 2D). These percentages corresponded to 157 , 248 , and $590 \mu \mathrm{g}$ of ${ }^{15} \mathrm{~N}$ derived from that applied during Stages I, II, and III, respectively, ending up in the inflorescence at this sampling point (Fig. 2D). Fertilizer $\mathrm{N}$ applied during Stage I constituted $16 \%$ [i.e., $157 /(157+248+590) \mu \mathrm{g}$ ] of the stored $\mathrm{N}$ translocated to the inflorescence at the visible bud stage; by similar calculations, the contributions of the $\mathrm{N}$ applied during Stages II and III were $25 \%$ and $59 \%$, respectively.

The allocation of fertilizer $\mathrm{N}$ applied during various stages to the Phalaenopsis inflorescence at the visible bud stage was investigated in both experiments of this study. The relative contributions of fertilizer $\mathrm{N}$ applied during the different stages to inflorescence development can thus be calculated. In Expt. 2, we found that fertilizer $\mathrm{N}$ stored during Stages I, II, and III constituted $16 \%, 25 \%$, and $59 \%$, respectively, of the stored $\mathrm{N}$ component of the $\mathrm{N}$ accumulated in the inflorescence. In Expt. 1, we determined that the ratio of fertilizer $\mathrm{N}$ applied during Stage III to that applied during spiking (corresponding to Stage IV in Expt. 2) that accumulated in the inflorescence was $31 \%: 69 \%$, respectively. Combining the two ratios, the ratio of fertilizer $\mathrm{N}$ applied during Stages I, II, III, and during spiking that accumulated in the inflorescence was 7\%:11\%:25\%:57\% (i.e., 16/59:25/59:59/59:69/31, obtained by setting the Stage III component, which is the common factor, to 1 ).

These results from the two experiments were obtained under conditions in which fertilization was ample. Definitely, under reduced fertilization, the contribution of $\mathrm{N}$ stored during the vegetative stage to inflorescence development may become more significant. In another study, we found that as fertilizer concentration was reduced from full-strength to $10 \%$-strength Johnson's solution, the ratio of fertilizer N applied during Stage III to that applied during spiking that later ended up in the inflorescence increased to $89 \%$ to $11 \%$; when no fertilizer was given, stored $\mathrm{N}$ became the sole source of $\mathrm{N}$ for the developing inflorescence (Susilo and Chang, 2014).

Vegetative plant parts of Phalaenopsis have N storage FUNCTION AND STORED N CAN BE EASILY MOBILIZED WITHIN THE PLANT. From the results of Expt. 2, we found that regardless of the stage of fertilizer application, the fertilizer $\mathrm{N}$ accumulated in roots decreased as the plants entered the subsequent stages in the vegetative period and thereafter the reproductive period (Fig. 2). This suggests the ability of Phalaenopsis roots to serve as storage organs for N. Similar results have been shown in our previous work (Susilo et al., 2013). The shoot also shows N storage capability, in which the $\mathrm{N}$ accumulated in the shoot during the vegetative stage was allocated to the inflorescence as the plants entered the reproductive stage; this is especially apparent for the $\mathrm{N}$ stored in the shoot during the small and medium plant stages [i.e., Stages I and II (Fig. 2C-E)].

High mobility of stored $\mathrm{N}$ was also evident from the results of Expt. 2. Fertilizer $\mathrm{N}$ stored during small and medium plant stages had similar mobility compared with fertilizer absorbed during the large plant stage (Fig. 2). For instance, $16 \%$ of the $\mathrm{N}$ accumulated during the large plant stage ended up in the inflorescence at the two-third flower open stage, and the corresponding percentages of the $\mathrm{N}$ stored during the medium and small plant stages were similar at $13 \%$ and $12 \%$, respectively (Fig. 2E). This means that in addition to being tied to immobile forms after absorption (e.g., for immobile cellular components or structural proteins), some of the absorbed $\mathrm{N}$ became part of a pool that can be mobilized. It is commonly known that $\mathrm{N}$ is a mobile nutrient with remobilization occurring during events such as a shift to the reproductive stage or leaf senescence (Marschner, 1997). In this study, we have quantified the mobilization of previously stored $\mathrm{N}$.

We also found that regardless of the stage at which $\mathrm{N}$ was stored by Phalaenopsis, the percentage of the stored $\mathrm{N}$ that was allocated to the inflorescence was similar (Fig. 2). In Expt. 2, fertilizer $\mathrm{N}$ applied to Phalaenopsis plants as young as 3 months out of flask still had a significant contribution to the stored $\mathrm{N}$ pool many months later. This result highlights the importance of consistent fertilization regimen throughout the long period of Phalaenopsis cultivation. This also explains that the nutrient storage capability of Phalaenopsis is the reason for its excellent resilience against nutrient deficiency stress, and, perhaps, partly explains why studies of nutrition in Phalaenopsis by different workers have yielded some inconsistent results (Lei, 2007; Wang, 2000, 2007; Yoneda et al., 1997; Yu, 2012).

In summary, the inflorescence is a major $\mathrm{N}$ sink during the reproductive stage of Phalaenopsis. Fertilizer applied during the reproductive stage is a significant $\mathrm{N}$ source for the inflorescence development of Phalaenopsis, whereby current fertilizer application supplies $57 \%$ of the $\mathrm{N}$ required for inflorescence development. Therefore, providing sufficient fertilizer $\mathrm{N}$ is important during the reproductive stage to ensure the quality of flowering. In addition, $\mathrm{N}$ stored during all stages of the vegetative period also contributes to flowering. Even when ample fertilization was given during the reproductive stage, $6 \%$ to $8 \%$ of the $\mathrm{N}$ accumulated during Stages I, II, and III ended up in the inflorescence at the visible bud stage, whereas at the two-third flowers open stage, $12 \%$ to $16 \%$ of the $\mathrm{N}$ accumulated in the plant during these three stages ended up in the inflorescence. Therefore, it is important to provide Phalaenopsis with ample $\mathrm{N}$ fertilization at its various growth stages.

\section{Literature Cited}

FloraHolland. 2013. Prijsinformatie FloraHolland week 30. 17 Sept. 2013. <http://www.floraholland.com/media/1773468/ Prijsinformatieweek30.PDF $>$ [in Dutch].

Guo, Y.A. 2012. Nitrogen uptake and distribution in Oncidium Gower Ramsey. MS thesis, Natl. Taiwan Univ., Taipei, Taiwan [in Chinese with English abstract].

Hauck, R.D. and J.M. Bremner. 1976. Use of tracers for soil and fertilizer nitrogen research. Adv. Agron. 28:219-266.

Johnson, C.M., P.R. Stout, T.C. Broyers, and A.B. Carlton. 1957. Comparative chlorine requirements of different plant species. Plant Soil 8:337-353.

Lee, N. and G.M. Lin. 1984. Effect of temperature on growth and flowering of Phalaenopsis white hybrid. J. Chinese Soc. Hort. Sci. 30:223-231 [in Chinese with English abstract].

Lei, H.Y. 2007. Changes of mineral composition and fertilizer requirement of Phalaenopsis during reproductive stages. MS thesis, Natl. Taiwan Univ., Taipei, Taiwan [in Chinese with English abstract].

Marschner, H. 1997. Mineral nutrition of higher plants. 2nd Ed. Academic Press, San Diego, CA.

Retamales, J.B. and E.J. Hanson. 1989. Fate of ${ }^{15} \mathrm{~N}$-labeled urea applied to mature highbush blueberries. J. Amer. Soc. Hort. Sci. 114:920-923. 
Runkle, E., Y.T. Wang, M. Blanchard, and R. Lopez. 2005. The orchid grower. Greenhouse Grower 23:64-67.

Schiltz, S., N. Munier-Jolain, C. Jeudy, J. Burstin, and C. Salon. 2005. Dynamics of exogenous nitrogen partitioning and nitrogen remobilization from vegetative organs in pea revealed by ${ }^{15} \mathrm{~N}$ in vivo labeling throughout seed filling. Plant Physiol. 137:1463-1473.

Susilo, H. and Y.C.A. Chang. 2014. Nitrogen source for inflorescence development in Phalaenopsis: II. Effect of reduced fertilizer level on stored nitrogen use. J. Amer. Soc. Hort. Sci 139:76-82.

Susilo, H., Y.C. Peng, S.C. Lee, Y.C. Chen, and Y.C.A. Chang. 2013. The uptake and partitioning of nitrogen in Phalaenopsis Sogo Yukidian 'V3' as shown by ${ }^{15} \mathrm{~N}$ as a tracer. J. Amer. Soc. Hort. Sci. 138:229-237.

U.S. Department of Agriculture. 2013. Floriculture crops 2012 summary. 17 Sept. 2013. <http://usda01.library.cornell.edu/usda/ current/FlorCrop/FlorCrop-04-25-2013.pdf>.
Wang, Y.T. 2000. Impact of a high phosphorus fertilizer and timing of terminating fertilization on flowering of a hybrid moth orchid. HortScience 35:60-62.

Wang, Y.T. 2007. Potassium concentration affects growth and flowering of Phalaenopsis in a bark mix or sphagnum moss substrate. HortScience 42:1563-1567.

Yoneda, K., M. Usui, and S. Kubota. 1997. Effect of nutrition deficiency on growth and flowering of Phalaenopsis. J. Jpn. Soc. Hort. Sci. 66:141-147 [in Japanese with English abstract].

Youssefi, F., S.A. Weinbaum, and P.H. Brown. 2000. Regulation of nitrogen partitioning in field-grown almond trees: Effects of fruit loads and foliar nitrogen applications. Plant Soil 227:273-281.

$\mathrm{Yu}$, Y.C. 2012. Growth response and gene expression profiling in Phalaenopsis under nitrogen, phosphorus, and potassium deficiency. MS thesis, Natl. Taiwan Univ., Taipei, Taiwan. 